ISSN 0258-7122 (Print), 2408-8293 (Online)

Bangladesh J. Agril. Res. 43(3): 395-406, September 2018

\title{
EFFECT OF FOLIAR APPLICATION OF IRON AND ZINC ON NUTRIENT UPTAKE AND GRAIN YIELD OF WHEAT UNDER DIFFERENT IRRIGATION REGIMES
}

\author{
S. SULTANA ${ }^{1}$, H. M. NASER ${ }^{2}$, M. A. QUDDUS ${ }^{3}$ \\ N. C. SHIL ${ }^{4}$ AND M. A. HoSSAIN ${ }^{5}$
}

\begin{abstract}
A field experiment was carried out to study the zinc-iron relationship in wheat (BARI Gom-26) plant grown under water stress condition in the field near net house of Soil Science Division, BARI, Joydebpur, Gazipur, during November 2015 to March 2016. The experiment was designed in a split plot on sixteen treatments comprising four irrigation treatments (regular irrigation, stopping irrigation at crown root initiation, stopping irrigation at booting stage and stopping irrigation at grain filling stage) and four foliar application of zinc and iron (control, $0.05 \%$ of zinc, $0.05 \%$ of iron and $0.05 \%$ of zinc $+0.05 \%$ of iron). Zinc sulphate monohydrate $\left(\mathrm{ZnSO}_{4} . \mathrm{H}_{2} \mathrm{O}\right)$ and ferrous sulphate $\left(\mathrm{FeSO}_{4}, \mathrm{H}_{2} \mathrm{O}\right)$ were used as a source of $\mathrm{Zn}$ and Fe. The highest yield $\left(4.01 \mathrm{tha}^{-1}\right)$ was recorded in stopping irrigation at grain filling stage which was identical with regular irrigation. Water stress at crown root initiation stage had the most negative effect on growth and yield. Foliar application of zinc and iron played a major role on yield and yield components of wheat at later stages of growth. The results obtained from the present research showed that iron and zinc spray increased grain yield and quality of wheat and improved the effects caused by drought stress.
\end{abstract}

Keywords: Wheat, foliar application, iron, zinc, yield.

\section{Introduction}

Increasing the zinc and iron concentration in food crop plants, resulting in better crop production and improved human health is an important global challenge. Micronutrient malnutrition, particularly $\mathrm{Zn}$ and Fe deficiency, affects over three billion people worldwide (Bouis, 2007). Producing micronutrient enriched cereals via biofortification, either agronomically or genetically, and improving $\mathrm{Fe}$ and $\mathrm{Zn}$ bioavailability are considered promising and cost effective approaches for diminishing malnutrition (Distelfeld et al., 2007). Foliar fertilizer sprays have

${ }^{1}$ Scientific Officer, Soil Science Division, Bangladesh Agricultural Research Institute (BARI), Joydebpur, Gazipur-1701, ${ }^{2 \& 4}$ Principal Scientific Officer, Soil Science Division, BARI, Joydebpur, Gazipur-1701, ${ }^{3}$ Senior Scientific Officer, HRC, BARI, Gazipur-1701, ${ }^{5}$ Chief Scientific Officer, Soil Science Division, BARI, Joydebpur, Gazipur-1701, Bangladesh. 
proved to be a sustainable, effective and low cost strategy to improve $\mathrm{Fe}$ and $\mathrm{Zn}$ levels in edible portions of staple food crops (Ling et al., 2013).

Foliar spraying is a new method for crop feeding in which micronutrients in form of liquid are sprayed on leaves (Nasiri et al., 2010). Foliar application of microelements is more beneficial than soil application. Since application rates are lesser as compared to soil application, same application could be obtained easily and crop reacts to nutrient application immediately (Zayed et al., 2011). Foliar spraying of microelements is very helpful when the roots cannot provide necessary nutrients (Babaeian et al., 2011). Moreover, soil pollution would be a major problem by micronutrients through soil application. Narimani et al. (2010) reported that microelements foliar applications improve the effectiveness of macronutrients. It has been found that microelements foliar application is in the same level and even more influential as compared to soil application. Resistance to different stresses will be increased by foliar application of micronutrients (Ghasemian et al., 2010).

Plant nutrition has an important role in raising level of plants tolerance against a variety of environmental stresses and in this regard, iron and zinc are the most important essential micronutrients in plant nutrition (Baybordy and Mamedov, 2010). Metal ions such as iron, zinc, copper, manganese and magnesium as a cofactor participate in construction of many antioxidant enzymes and results of Cakmak et al. (2010) studies showed that under micronutrients deficiency conditions, antioxidant enzyme activities decrease and thus increases the sensitivity of plants to environmental stresses. Thalooth et al. (2006) reported that foliar application of zinc sulfate in water stress conditions had a positive effect on growth, yield and yield component of mungbean plant. Experimental result of Odeley and Animashaun (2007) also showed that foliar application of micronutrients increased the soybean yield, quality, resistance to pests and diseases and drought stress. Therefore, the micronutrients such as iron, copper, boron, zinc and manganese have many contributions in cell wall formation and plant resistance to pests and diseases and environmental stresses.

The micronutrients play an important role in increasing crop yield. Micronutrients have prominent effects on dry matter, grain yield and straw yield in wheat (Asad and Rafique, 2000). Zinc and Fe are involved in detoxification of reactive oxygen specious (ROS) and they are also important for reducing the production of free radicals by superoxide radical producing enzymes (Cakmak, 2000). Iron plays a key role in biological redox system, enzyme activation and oxygen carrier in nitrogen fixation (Weisany et al., 2013). Previously, many reports have evaluated the response of wheat to micronutrients (soil or foliage) application but little information is available regarding combined application of micronutrients. This experiment was conducted to evaluate the role of mixed 
application of micronutrients in improving wheat performance under water different irrigation regimes.

\section{Materials and Methods}

A field experiment was carried out in the field near net house of Soil Science Division of the Bangladesh Agricultural Research Institute (BARI), Joydebpur, Gazipur during November, 2015 to March, 2016 with a view to studying zinciron relationship in wheat plant grown under water stress condition. The experiment was arranged as split plot based on randomized complete block design with three replications. Main plots included irrigation period with three levels (irrigation at CRI stage, booting stage and grain filling stage) and sub-plots were treatments of $\mathrm{Zn}, \mathrm{Fe}$ and $\mathrm{Zn}+\mathrm{Fe}$ foliar application and control (water foliar application). BARI Gom-26 variety was tested. Each split plot was $2 \mathrm{~m}^{2}$ in size with $0.5 \mathrm{~m}$ border distance.

Table 1. Initial properties of the soil samples of experimental field

\begin{tabular}{|c|c|c|c|c|c|c|c|c|c|c|c|c|c|}
\hline \multirow{2}{*}{$\begin{array}{c}\text { Soil } \\
\text { Properties }\end{array}$} & \multirow{2}{*}{ Texture } & \multirow{2}{*}{$\mathrm{pH}$} & \multirow{2}{*}{$\begin{array}{l}\mathrm{OM} \\
(\%)\end{array}$} & $\mathrm{Ca}$ & $\mathrm{Mg}$ & $\mathrm{K}$ & \multirow{2}{*}{$\begin{array}{c}\text { Total N } \\
\%\end{array}$} & $\mathrm{P}$ & $\mathrm{S}$ & $\mathrm{B}$ & $\mathrm{Cu}$ & $\mathrm{Fe}$ & $\mathrm{Zn}$ \\
\hline & & & & \multicolumn{3}{|c|}{ meq $100 \mathrm{~g}^{-1}$} & & \multicolumn{6}{|c|}{$\mu \mathrm{g} \mathrm{g}^{-1}$} \\
\hline Result & $\begin{array}{c}\text { Sandy } \\
\text { clay loam }\end{array}$ & 7.7 & 1.06 & 6.5 & 2.2 & 0.21 & 0.056 & 3.6 & 29.7 & 0.20 & 2.4 & 24.6 & 3.46 \\
\hline $\begin{array}{c}\text { Critical } \\
\text { level }\end{array}$ & - & Alkaline & - & 2.0 & 0.5 & 0.12 & - & 10.0 & 10 & 0.2 & 0.2 & 4.0 & 0.6 \\
\hline
\end{tabular}

Table 2. Moisture status of soil at different days during the study

\begin{tabular}{|c|c|c|c|c|c|c|c|}
\hline \multirow[b]{2}{*}{ Treatment } & \multicolumn{7}{|c|}{ Moisture status (\%) of $0-15 \mathrm{~cm}$ depth of soil } \\
\hline & Initial & $\begin{array}{c}18 \\
\text { DAS }\end{array}$ & $\begin{array}{c}40 \\
\text { DAS }\end{array}$ & $\begin{array}{c}55 \\
\text { DAS }\end{array}$ & $\begin{array}{c}70 \\
\text { DAS }\end{array}$ & $\begin{array}{c}85 \\
\text { DAS }\end{array}$ & $\begin{array}{c}100 \\
\text { DAS }\end{array}$ \\
\hline $\begin{array}{c}\mathrm{T}_{1}=\text { Control (regular } \\
\text { irrigation) }\end{array}$ & 17 & 15.3 & 18.1 & 15.1 & 18.3 & 20.5 & 10.6 \\
\hline $\begin{array}{l}\mathrm{T}_{2}=\text { Skipping irrigation at CRI } \\
\text { stage }\end{array}$ & 17 & 13.4 & 15.5 & 12.5 & 10.3 & 15.1 & 9.50 \\
\hline $\begin{array}{c}\mathrm{T}_{3}=\text { Skipping irrigation at } \\
\text { booting stage }\end{array}$ & 17 & 15.5 & 13.3 & 11.7 & 13.2 & 14.6 & 8.40 \\
\hline $\begin{array}{c}\mathrm{T}_{4}=\text { Skipping irrigation at } \\
\text { heading \& flowering } \\
\text { stage }\end{array}$ & 17 & 14.3 & 15.6 & 13.5 & 13.5 & 11.0 & 6.50 \\
\hline
\end{tabular}

There were sixteen treatment combinations comprising four irrigation treatments, i.e $\mathrm{T}_{1}$ : full irrigation (unstressed); irrigation at crown root initiation stage, booting 
stage and grain filling stage, $\mathrm{T}_{2}$ : stressed by stopping one irrigation at crown root initiation stage, $\mathrm{T}_{3}$ : stressed by stopping one irrigation at booting stage, $\mathrm{T}_{4}$ : stressed by stopping one irrigation at grain filling stage and four levels of foliar sprays are $\mathrm{F}_{1}$ : control (foliar application of distilled water), $\mathrm{F}_{2}$ : foliar application of $0.05 \%$ of $\mathrm{Zn}, \mathrm{F}_{3}$ : foliar application $0.05 \%$ of $\mathrm{Fe}$ and $\mathrm{F}_{4}$ : foliar application of $0.05 \%$ of $\mathrm{Zn}$ and $0.05 \%$ of $\mathrm{Fe}$. Foliar application of zinc and iron was done during the stopping irrigation at respective days. Zinc sulphate monohydrate $\left(\mathrm{ZnSO}_{4} . \mathrm{H}_{2} \mathrm{O}\right)$ and ferrous sulphate $\left(\mathrm{FeSO}_{4} . \mathrm{H}_{2} \mathrm{O}\right)$ were used as a source of zinc and iron. Urea, TSP, MP, gypsum and boric acid were used as a source of N, P, $\mathrm{K}, \mathrm{S}$ and $\mathrm{B}$, respectively. Fertilizers were applied based on BARC fertilizer recommendation guide-2012. All PKSB and half of $\mathrm{N}$ were applied at the final land preparation and the remaining half of $\mathrm{N}$ was applied before booting stage. The crops were harvested on 04 March 2016 at full maturity. Ten plants from each plot were sampled randomly for collection of different plant characters and yield attributes. Data on yield and yield contributing characters such as plant height $(\mathrm{cm})$, spike length $(\mathrm{cm})$, grain spike ${ }^{-1}, 100$ grain wgt, yield $\left(\mathrm{t} \mathrm{ha}^{-1}\right)$ were recorded. Plants of $1 \mathrm{~m}^{2}$ area from each plot were selected for data collection. Soil moisture data collected at different growth stages of wheat are shown in Table 2. Weather data during the crop growth period are presented on Fig 1. Data on yield and yield contributing parameters were recorded and statistically analyzed with the help of statistical package MSTAT-C and mean separation was tested by Duncan's Multiple Range Test (DMRT). Moisture content in soil was calculated by using the following formula.

$$
\text { Soil Moisture }(\%)=\frac{\text { Wet soil }(\mathrm{g})-\text { Dry soil }(\mathrm{g})}{\text { Dry soil }(\mathrm{g})} \times 100
$$

\section{Methods of chemical analysis}

Initial soil samples collected from $0-15 \mathrm{~cm}$ depth prior to fertilizer application, were analyzed for all important soil parameters using standard procedures (Table 1). The soil was found to be Alkaline. Standard methods were used in these determinations. Soil $\mathrm{pH}$ was measured by a combined glass calomel electrode. Organic carbon was determined by the wet oxidation method. Total $\mathrm{N}$ was determined by a modified Kjeldahl method. Calcium $(\mathrm{Ca})$, magnesium $(\mathrm{Mg})$ and $\mathrm{K}$ were determined by $\mathrm{NH}_{4} \mathrm{OAc}$ extractable method, copper $(\mathrm{Cu})$, iron $(\mathrm{Fe})$, manganese $(\mathrm{Mn})$ and zinc $(\mathrm{Zn})$ were determined by DTPA extraction followed by AAS reading. Boron (B) was determined by $\mathrm{CaCl}_{2}$ extraction method. Available $\mathrm{P}$ was determined by the Bray and Kurtz method while $\mathrm{S}$ was determined using the turbidimetric method with $\mathrm{BaCl}_{2}$. 


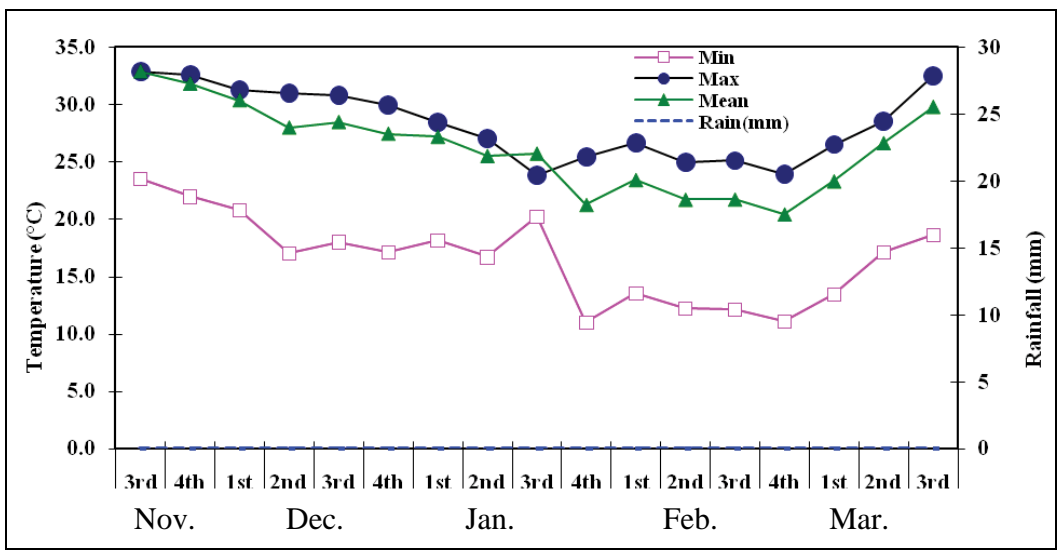

Figure 1. Rainfall, minimum, maximum and mean air temperature during growing period.

\section{Results and Discussion}

\section{Effect of irrigation}

The effect of irrigation on the grain yield and yield components of wheat has been shown in Table 3. The highest grain yield $\left(4.01 \mathrm{t} \mathrm{ha}^{-1}\right)$ was obtained in $\mathrm{T}_{4}$ treatment (stopping irrigation at grain filling stage) which was identical with $T_{1}$ treatment (regular treatment). The lowest yield $\left(3.02 \mathrm{t} \mathrm{ha}^{-1}\right)$ was obtained from stopping irrigation at crown root initiation stage $\left(T_{2}\right)$ which was significantly lower than other treatments. This finding revealed that crown root initiation was the most critical stage for irrigation and its omission at this stage reduced the grain yield. CRI stage is the most critical stage for irrigation in wheat, because any shortage of moisture at this stage results in less tillering and great reduction in yield. Bajwa et al., (1993) reported that number of tillers improved with irrigation at crown root stage and better grain yield was recorded with irrigation at crown root and booting stage.

\section{Effect of foliar application of zinc and iron}

The effect of foliar application of zinc and iron on the grain yield and yield components of wheat has been shown in (Table 3). Foliar application of zinc and iron played a significant role on the yield and yield components of wheat. The highest grain yield $\left(4.02 \mathrm{t} \mathrm{ha}^{-1}\right)$ was obtained by using $(\mathrm{Fe}+\mathrm{Zn})$ treatment. Due to the enzymatic activity enhancement, microelements effectively increased photosynthesis and translocation of assimilates to the seed. Foliar application of $\mathrm{Fe}$ and $\mathrm{Zn}$ increased grain yield and protein content (Seilsepour, 2007). Chaudry et al. (2007) reported that micronutrients ( $\mathrm{Zn}, \mathrm{Fe}, \mathrm{B})$ significantly increased the wheat yield over control when applied in single and in combination, along with basal dose of NPK, whilst Mandal et al. (2007) noticed significant optimistic 


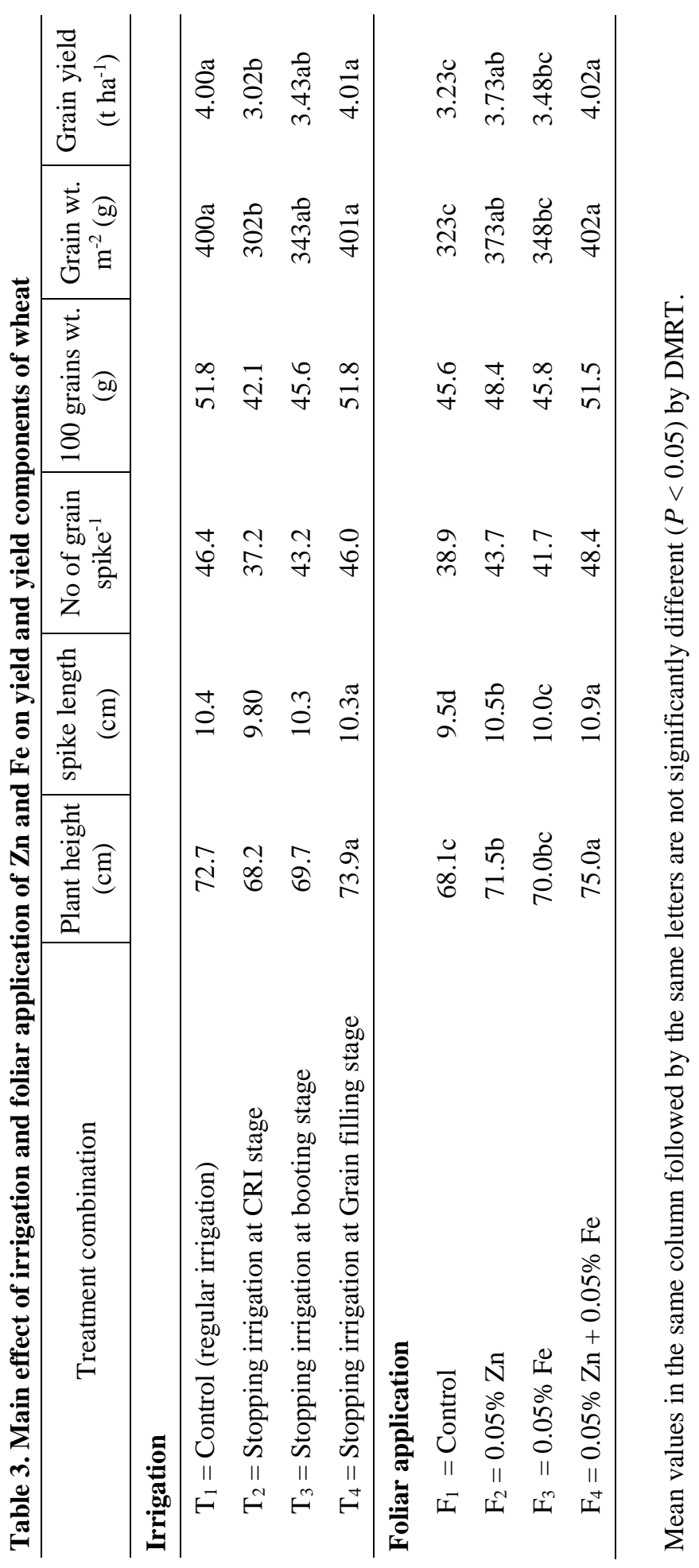




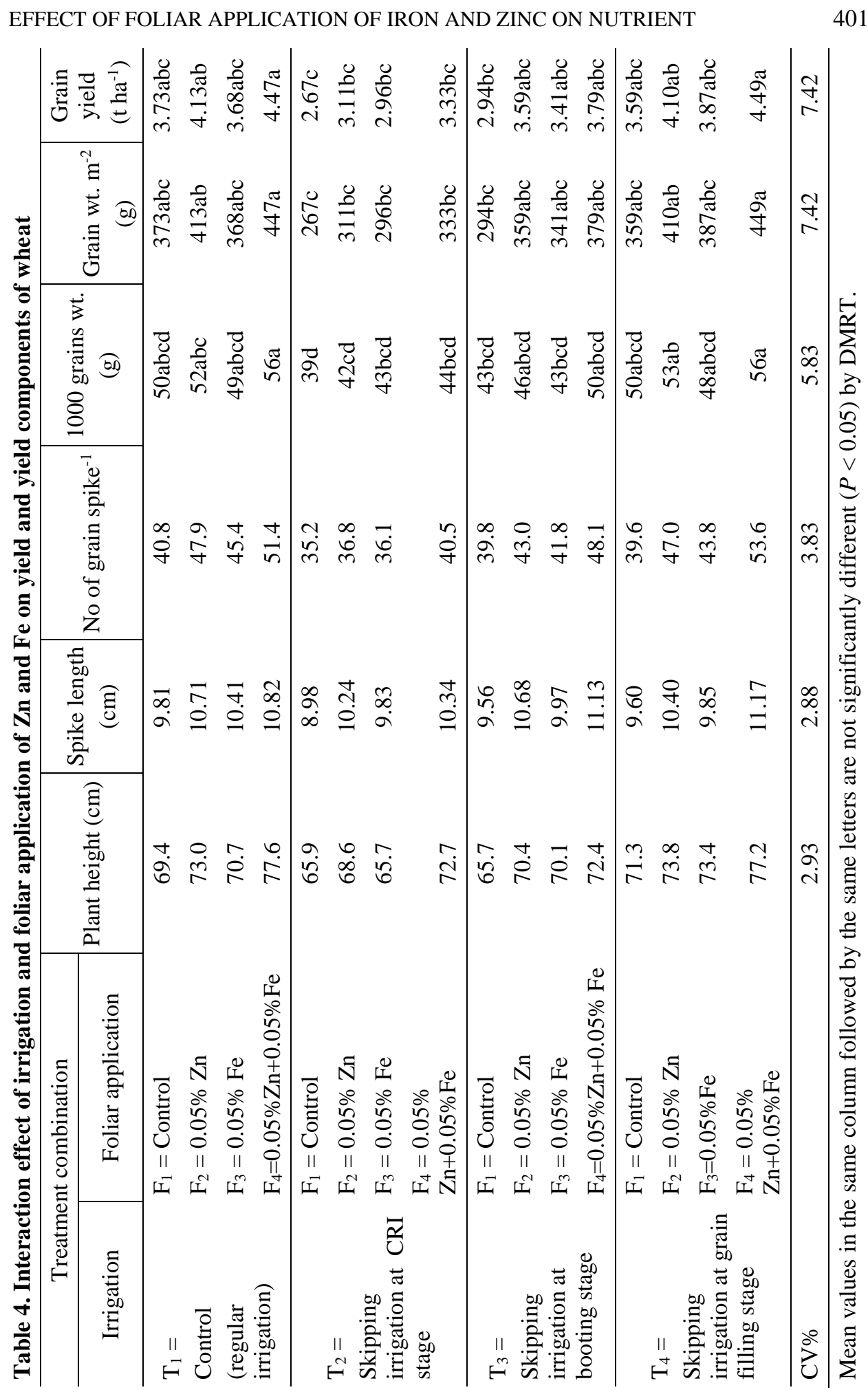




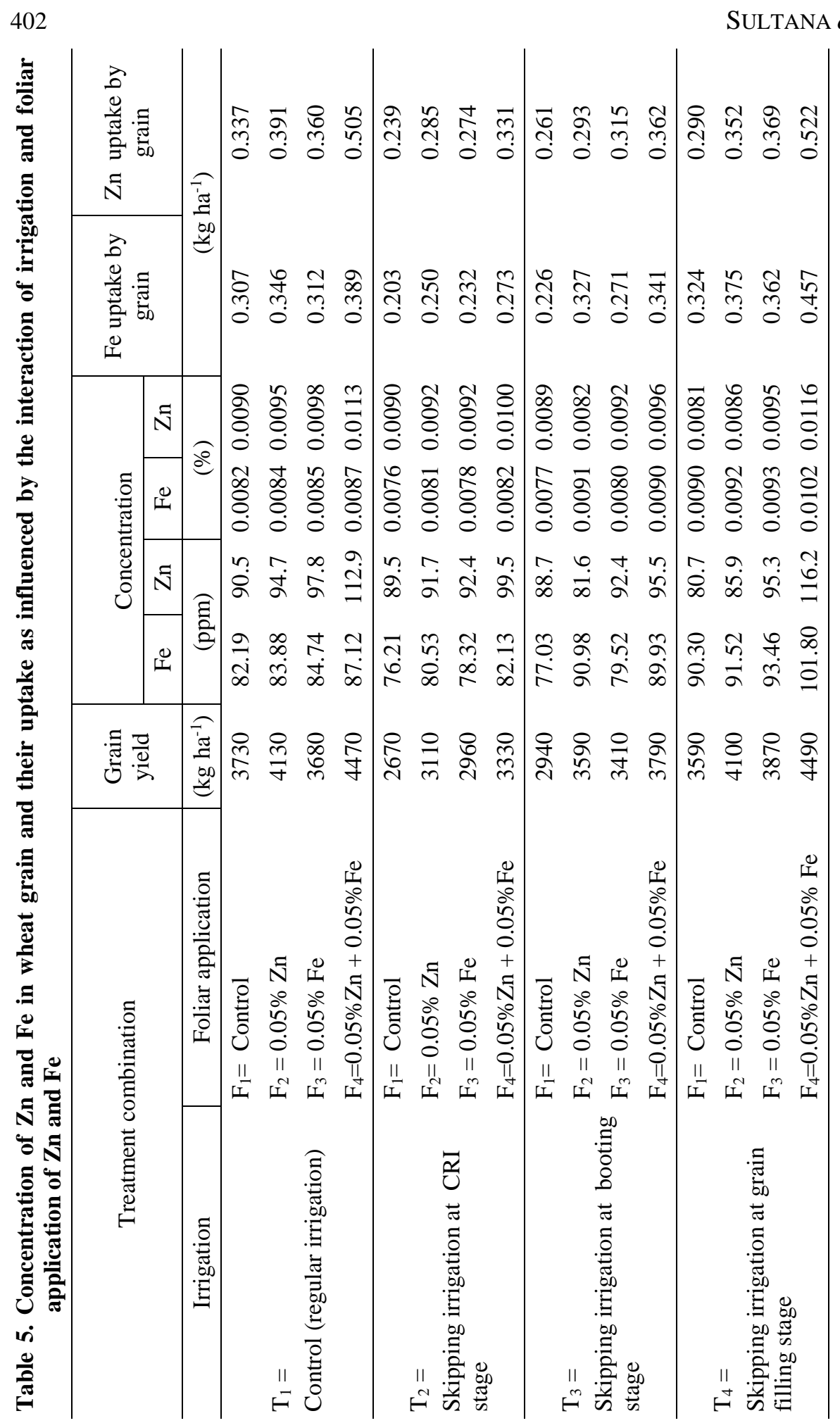


interaction among physiological stages of wheat growth and fertilizer treatments. Bameri et al. (2012) showed that foliar micronutrient application ( $\mathrm{Fe}, \mathrm{Zn}$, and Mn) significantly improved the plants height, number of spike per plant, number of grain per spike, 1000-grain weight, grain yield, biological yield and harvest index. Application of $\mathrm{Fe}$ and $\mathrm{Zn}$ alone or combination had positive effect on grain yield and its components. Zain et al. (2015) showed that the application of micronutrients $(\mathrm{Fe}, \mathrm{Zn}$ and $\mathrm{Mn}$ ) substantially improved plant height, spike length $\mathrm{cm}$, spikelets per spike, grains per spike, 1000-grain weight, number of tillers square meter, grain yield, biological yield and harvest index of wheat. Zayed et al. (2011) announced that due to the synergistic effect, zinc + iron treatment as compared to $\mathrm{Zn}$ treatment and $\mathrm{Fe}$ treatment was more helpful in rice. Kobraee et al. (2011) claimed that zinc and iron application at the same time could be lead to higher dry matter and seed yield as compared to using them separately. Foliar application with micronutrients $(\mathrm{Fe}, \mathrm{B}$ and $\mathrm{Zn})$ might be due to their critical role in crop growth, involving in photosynthesis processes, respiration and other biochemical and physiological activates and thus their importance in achieving higher yields (Salih, 2013). Habib (2012) obtained significant increase in 1000kernels weight when $\mathrm{Zn}$ and $\mathrm{Zn}+\mathrm{Fe}$ supplied on foliage at grain filling period of wheat in comparison with $\mathrm{Fe}$ supplement without affecting grain numbers per spike. Zeidan et al. (2010) recorded significant increase in all grain yield parameters and straw yield when $\mathrm{Zn}$ and $\mathrm{Fe}$ were sprayed on foliage at tillering and booting stage.

\section{Interaction effects of irrigation and foliar application of zinc and iron}

The interaction effect between irrigation and foliar application of zinc and iron on the grain yield and yield components of wheat was statistically significant (Table 4). The highest weight of 1000 seed $(56 \mathrm{~g})$ was recorded in $\mathrm{T}_{4}$ treatment (stopping irrigation in grain filling stage) with a mixture of zinc and iron which was statistically identical to $\mathrm{T}_{1}$ treatment (regular irrigation). The highest yield (4.49 $\mathrm{t} / \mathrm{ha}$ ) was recorded on $\mathrm{T}_{4}$ treatment (stopping irrigation at grain filling stage with foliar spray of zinc and iron), which was followed by $\mathrm{T}_{1}$ treatment (regular irrigation with foliar spray of zinc and iron), but the variation was nonsignificant. Stopping irrigation at crown root initiation of growth caused the reduction in all yield components and grain yield. The lowest grain yield $(2.67 \mathrm{t}$ $\mathrm{ha}^{-1}$ ) was recorded from $\mathrm{T}_{2}$ treatment (stopping irrigation at crown root initiation stage). This might be due to disturbance of crown root development which decreased the grain yield significantly. Foliar application of zinc and iron at grain filling stage was more effective in alleviating the adverse effect of water deficit on grain yield. Many current and past researches pointed soil and/or foliage supplied $\mathrm{Zn}$ and $\mathrm{Fe}$ can increase the accumulation of $\mathrm{Zn}$ and $\mathrm{Fe}$ in wheat grain, respectively (Kutman et al., 2010; Habib, 2012; Kutman et al., 2012). Micronutrients fertilizer when applied at milking dough stage of grain increase 
the mineral contents of grain and improved its nutritional quality (Zhang et al., 2010). Translocation of nutrients from the old to young leaves and leaves or stem to grains occur through phloem transport system and translocation ranges from utilization to storage sinks (Campbell and Reece, 2002). In case of wheat plant, grain resembles the storage sink and rest as utilization sink. Thus the availability of $\mathrm{Zn}$ and $\mathrm{Fe}$ at later stage of plant development particularly at grain filling period could increase the uptake as well as concentration of these elements in wheat grain (sink). The iron and zinc element in stress condition have an enhancing role on osmotic adjustment process (due to the increase of soluble carbohydrates). Under drought stress conditions the role of these elements can be seen as a contributor to osmotic regulation that with intervention in the synthesis of osmotic compounds for compatibility with stress and maintain turgor pressure performed their roles (Akbari et al., 2013).

\section{Iron and $\mathrm{Zn}$ content in wheat grain}

The concentration of $\mathrm{Zn}$ in wheat grain ranged from 76.2 to $101.80 \mathrm{ppm}$ (Table 5). Drought at grain filling stage treatment $\left(\mathrm{T}_{4}\right)$ showed significantly higher content of $\mathrm{Zn}$ in grain compared to other treatments. The concentration of $\mathrm{Fe}$ in wheat grain ranged from 80.7 to $116.2 \mathrm{ppm}$ (Table 5). Drought at grain filling stage treatment $\left(\mathrm{T}_{4}\right)$ showed significantly higher content of Fe in grain compared to other treatment. Ling et al. (2013) demonstrated that foliar Fe amino acid and a relatively low concentration of $\mathrm{ZnSO}_{4} .7 \mathrm{H}_{2} \mathrm{O}$ significantly increase the $\mathrm{Fe}$ and $\mathrm{Zn}$ concentration in brown rice of different cultivars. Indeed, many previous studies have also reported a positive correlation between grain $\mathrm{Zn}$ and $\mathrm{Fe}$ concentrations in cereals (Cakmak et al., 2004; Morgounov et al., 2007).

\section{Conclusion}

It can be concluded that the foliar application of zinc and iron fertilizers have positive effect on growth, yield components and grain yield by wheat when plants are not able to absorb the iron and zinc from soil due to high soil $\mathrm{pH}$. As a result, foliar application of zinc and iron develops plant growth, grain yield and enhances its quality. Under drought stress, foliar application of zinc and iron improved yield of wheat, grain filling stage being more responsive.

\section{References}

Akbari O.S., C. H. Chen, J.M. Marshall, H. Huang, I. Antoshechkin, et al. 2013. A synthetic gene drive system for local, reversible modification and suppression of insect populations. Curr. Biol. 23: 671-677.

Asad, A. and R. Rafique. 2000. Effect of zinc, copper, manganese and boron on the yield and yield components of wheat crop in Tehsil Peshawar. Pakistan J. Biol. Sci. 3: $1615-1620$. 
Babaeian, M., I. Piri, A. Tavassoli, Y. Esmaeilian, H. and Gholami, 2011. Effect of water stress and micronutrients (Fe, $\mathrm{Zn}$ and $\mathrm{Mn}$ ) on chlorophyll fluorescence, leaf chlorophyll content and sunflower nutrient uptake in Sistan region. African J. Agric. Res. 6(15): 3526-3531.

Bajwa, M.A., M.H. Chaudhry, and A. Sattar, 1993. Influence of different irrigation regimes on yield and yield components in wheat. Pak. J. Agric. Res. 14: 361-365.

Bameri, M., R. Abdolshahi, G. Mohammadi-Nejad, K. Yousefi, and S.M. Tabatabaie. 2012. Effect of Different Microelement Treatment on Wheat (Triticum aestivum) Growth and Yield. Int. Res. J. Basic and Applied Sci. 3: 219-223.

Baybordy, A. and G. Mamedov. 2010. Evaluation of Application methods efficiency of zinc and iron for canola (Brassica napus L.). Notulae Scientia Biologicae. 2(1): 94 103.

Bouis, H.E. 2007. The potential of genetically modified food crops to improve human nutrition in developing countries. J. Dev. Studies. 43: 79-96.

Cakmak, I. 2000: Possible role of zinc in protecting plant cells from damage by reactive oxygen species. New Phytologist. 146: 185-205.

Cakmak, I., A. Torun, E. Millet, T. Fahima. A. Korol, E. Nevo, et al, 2004. Triticum dicoccoides: an important genetic resource for increasing zinc and iron concentration in modern cultivated wheat. Soil Sci. Plant Nutr. 50:1047-1054.

Cakmak, I., W.H. Pfeiffer, and B. McClafferty. 2010. Biofortification of durum wheat with zinc and iron. Cereal Chem. 87: 10-20.

Campbell, N.A. and J.B. Reece. 2002. Biology. 6th ed. San Francisco, CA, Benjamin Cummings, USA.

Chaudry, E.H., V. Timmer, A.S. Javed, and M.T. Siddique. 2007. Wheat response to micronutrients in rainfed areas of Punjab. Soil \& Environ. 26(1):97-101.

Distelfeld, A., I. Cakmak, Z. Peleg, L. Ozturk, A.M. Yazici, H. Budak, Y. Saranga, and T. Fahima, 2007. Multiple QTL-effects of wheat Gpc-B1 locus on grain protein and micronutrient concentrations. Physiol Plant. 129: 635-643.

Ghasemian, V., A. Ghalavand, A. Soroosh, and A. Pirzad. 2010. The effect of iron, zinc and manganese on quality and quantity of soybean seed. J. Phytol. 2:73-79.

Habib, M. 2012. Effect of supplementary nutrition with Fe, Zn chelates and urea on wheat quality and quantity. Afr. J. Biotechnol. 11(11): 2661-2665.

Kobraee, S. and K. Shamsi. 2011. Determination of zinc, iron and manganese concentration and partitioning during reproductive stages of soybean grown under field conditions. Res. Crops. 12(3): 752-760.

Kutman, U. B., B. Yildiz, L. Ozturk, and I. Cakmak. 2010. Biofortification of durum wheat with zinc through soil and foliar applications of nitrogen. Cereal Chem. 87: 19.

Kutman. U.B., B.K. Yildiz, Y. Ceylan, E.A. Ova, and I. Cakmak. 2012. Contributions of root uptake and remobilization to grain zinc accumulation in wheat depending on post-anthesis zinc availability and nitrogen nutrition. Plant Soil. 361: 177-187. 
Ling, Y., L. Wu, C. Yanga, and Q. Lva. 2013. Effects of iron and zinc foliar applications on rice plants and their grain accumulation and grain nutritional quality. Sci Food Agric. 93: 254-261.

Mandal, A., A.K. Patra, D. Singh, A. Swarup, and R.E. Masto. 2007. Effect of long-term application of manure and fertilizer on biological and biochemical activities in soil during crop development stages. Bioresoure Technol. 98(18): 3585-3592.

Morgounov, A., H.F. Gomez-Becerram, and A. Abugalieva. 2007. Iron and zinc grain density in common wheat grown in Central Asia. Euphytica. 155:193-203.

Narimani, H., M.M. Rahimi, A. Ahmadikhah, and B. Vaezi. 2010. Study on the effects of foliar spray of micronutrient on yield and yield components of durum wheat. Arch. Appl. Sci. Res. 2(6): 168-176.

Nasiri, Y., S. Zehtab-Salmasi, S. Nasrullahzadeh, N. Najafi, and K. GhassemiGolezani, 2010. Effects of foliar application of micronutrients (Fe and $\mathrm{Zn}$ ) on flower yield and essential oil of chamomile (Matricaria chamomilla L.). J. Med. Plants Res. 4(17): 1733-1737.

Odeley, F. and M.O. Animashaun,. 2007. Effects of nutrient foliar spray on soybean growth and yield (Glycine max L.) in south west Nigeria. Australian J. Crop Sci. 41: $1842-1850$.

Seilsepour, M. 2007. The study of fe and zn effects on quantitative and qualitative parameters of winter wheat and determination of critical levels of these elements in Varamin plain soils. Pajouhesh \& Sazandegi. 76: 123-133.

Salih, H.O. 2013. Effect of Foliar Fertilization of Fe, B and Zn on nutrient concentration and seed protein of Cowpea "Vigna Unguiculata. 2013. IOSR J. Agric. Veterinary Sci. 6(3): 42-46.

Thalooth, A.T., M.M. Tawfik, and M.H. Magda, 2006. Comparative study on the effect of foliar application of zinc, potassium and magnesium on growth, yield and some chemical constituents of mungbean plants grown under water stress conditions. World J. Agric. Sci. 2(1): 37-46.

Weisany, W., Y. Yaghoub Raei, and K.H. Allahverdipoor. 2013. Role of Some of Mineral Nutrients in Biological Nitrogen Fixation. Bulletin of Environment, Pharmacology and Life Sci. 2 (4): 77-84.

Zain, M., I. Khan, R.W.K. Qadri, U. Ashraf, S. Hussain, S. Minhas, A.A. Siddique, M.M. Jahangir, M. Bashir. 2015. Foliar Application of Micronutrients Enhances Wheat Growth, Yield and Related Attributes. American J. Plant Sci. 6: 864-869.

Zayed, B.A., A.K.M. Salem, H.M. El-Sharkawy. 2011. Effect of different micronutrient treatments on rice (Oriza sativa L.) growth and yield under saline soil conditions. World J. Agric. Sci. 7(2): 179-184.

Zeidan, M.S., F.M. Manal, and H.A. Hamouda. 2010. Effect of foliar fertilization of Fe, $\mathrm{Mn}$ and $\mathrm{Zn}$ on wheat yield and quality in low sandy soils fertility. World J. Agric. Sci. 6(6): 696- 699 .

Zhang, Y., R. Shi, K.M.D. Rezaul, F. Zhang, C. Zou. 2010. Iron and zinc concentration in grain and flour of winter wheat as affected by foliar application. J. Agric Food Chem. 58:12268-12274. 